\title{
RETENTION FACTORS OF MANAGEMENT STAFF IN THE MAINTENANCE PHASE OF THEIR CAREERS IN LOCAL GOVERNMENT
}

\section{Authors:}

Mervin Munsamy ${ }^{1}$

Anita Bosch Venter

\section{Affiliations:}

${ }^{1}$ Department of Industrial

Psychology and People

Management, University of

Johannesburg, South Africa

\section{Correspondence to:}

Anita Bosch Venter

e-mail:

anitav@uj.ac.za

\section{Postal address:}

PO Box 524, Auckland Park, 2006, South Africa

\section{Keywords:}

employer value proposition; EVP; retention factors; local government; maintenance career phase

\section{Dates:}

Received: 03 Mar. 2009

Accepted: 14 Aug. 2009

Published: 20 Oct. 2009

How to cite this article:

Munsamy, M., \& Bosch

Venter, A. (2009). Retention factors of management staff in the maintenance phase of their careers in local government. $S A$ Journal of Human Resource Management/SA Tydskrif vir Menslikehulpbronbestuur,

7(1), Art. \#198, 9 pages. DOI: 10.4102/sajhrm.v7i1.198

\section{This article is available} at: http://www.sajhrm.co.za

(C) 2009. The Authors. Licensee: OpenJournals Publishing. This work is licensed under the Creative Commons Attribution License.

\begin{abstract}
Organisations require an employer value proposition (EVP) to attract and retain people in management. This study was undertaken to understand the key retention factors that influence experienced management employees, in the maintenance phase of their careers, to remain employed at a local government organisation. Retention factors inform the organisation's EVP. A qualitative, empirical-analytical research paradigm with a modernist approach was adopted. Data were obtained through purposive sampling $(n=10)$ by way of semi-structured interviews. A theoretical framework was used against which data could be deducted and compared. Sixteen key factors were identified, of which Job Aligned with Personal Meaning or Passion emerged as the strongest retention factor among the study's participants.
\end{abstract}

\section{INTRODUCTION}

This article is intended to address retention issues in local government, and is therefore aimed at human resource practitioners and managers in this sector. The importance of employee commitment and loyalty has never been more significant than in today's context, where the 'war for talent' is rife, and skilled employees have a greater choice of employment, both locally and globally (De Villiers, 2006). This trend has had a particularly negative effect on the retention of professional and management employees within the public sector at local government level, since financial rewards are generally lower than in the private sector (Saratoga Institute, 2005). Employee retention rates show a direct, positive correlation with sales growth (Batt, 2002) and customer retention rates (Shaw, Duffy, Johnson \& Lockhart, 2005). The retention of talented and skilled employees has proved to strengthen an organisation, which is why specific attention should be given to the trend of managers who leave within their first two to three years of employment in the public sector. Only after approximately two years is it most likely that these employees will be in a position to add value to an organisation by playing to their strengths and being innovative (Buckingham \& Clifton, 2001). It is crucial that local government organisations retain these individuals to ensure that the transfer of skills takes place, thereby ensuring continuity and sustainability of ongoing initiatives.

What are the key factors that influence professional and management employees to remain employed in local government? This is the salient question that this study aimed to address. Marriot (2001) advocates that a key challenge facing organisations today is employee retention. Organisations face intense competition with almost all strategies being easily replicable by competitors. They are increasingly realising that people are perhaps the only real differentiator that can gain the organisation competitive advantage (Bell, 2005). Moreover, Byham, Smith and Paese (2002) cite rapid growth, a dramatic rise in retirements, poaching of key people by competitors and the difficulty of retaining talented people as critical challenges facing organisations at both executive and management levels. A lack of opportunities regarding both personal growth and job challenge are reasons why people voluntarily leave companies (Axel, 1998 and SHRM, 1997, cited in Byham et al., 2002). The national skills shortage leads to an abundance of vacant positions, which results in the increased mobility of skilled individuals. These employees require compelling reasons to remain with an organisation, which makes it essential for companies to have an understanding of what employees expect from employment (Britton, Chadwick \& Walker, 1999).

Ingham (2006) suggests that many surveys show effective management of an organisation's talent as one of business leaders' most critical challenges, since 'the acquisition, allocation, development and succession of the most important value adding people ... best create competitive advantage' (p. 20). In building competitive advantage by leveraging talent or skilled employees, managers face a job market in which employees constantly reassess their firm's employer value proposition (EVP). An EVP is described as the value or benefit an employee perceives to gain or experience by serving as a member of the organisation, or from their employer (Heger, 2007; Zingheim \& Schuster, 2006). An EVP is also defined as the measurement of the balance between an employee's performance and what he or she receives from the employer in return. It is an employee's perception whether what he or she 'receives' equals or exceeds what he or she 'gives', which is in line with equity theory (Noe, Hollenbeck, Gerhart \& Wright, 2008; Peterson, 2007). Organisations face potential for turnover when employees perceive their organisation's EVP to be less competitive than that of other organisations, or to what these others 'give'. From an employee's perspective, the fundamental EVP is a job and a working environment that meets his or her expectations (Lowe \& Schellenberg, 2002). Therefore, in answering the salient question, 'What are the key factors that influence professional and management employees to remain employed in local government?', the organisation will be able to use the findings to inform its EVP.

Applying these views to local government as an employer, it is equally important to have a competitive EVP, as the right calibre of human resources enables service delivery to communities. The mandate of a developmental local government is the provision of democratic and accountable governance to local communities, ensuring the provision of services in a sustainable manner, the promotion of social and economic development, the provision of a safe and healthy environment, and the encouragement of the involvement of communities and community organisations in matters of local government (South 
TABLE 1

Four attractors and retainers (Corporate Leadership Council, 2002)

\section{COMPENSATION AND BENEFITS}

Compensation and benefits must be market-related, and mechanisms should also be in place to reward and retain top performers.

\section{WORK ENVIRONMENT}

The work environment must be challenging and offer real learning and growth. Job profiles should be flexible to make positions more attractive, for example by removing bureaucratic work from these jobs. Catering for internal mobility, vertically and horizontally, together with recognition, role clarity and relevant responsibility, are key to the attraction and retention of high-value employees.

ORGANISATIONAL ENVIRONMENT

WORK-LIFE BALANCE

Issues here include the prestige and reputation of the organisation and the work. Creating an attractive image and place to work requires a more proactive marketing and communication strategy, the publication of success stories, and an emphasis on learning and innovation and on the importance of the work. Access to leading-edge technology is an important pull factor for high-end, ambitious employees.

Africa, 1996, pp. 151-164). These constitutional stipulations suggest a shift in focus from the importance of service delivery towards measurement of the impact of service delivery in relation to community needs. This suggests severe implications for the human resources required to capacitate a public service organisation to deliver on its mandate. Moreover, the retention of the skilled professionals and management grouping of employees becomes critical to ensure sustainability of longterm initiatives within such an organisation. Retention can be facilitated by determining and utilising an EVP, as it then becomes the basis for 'the deal' with the employee (Ingham, 2006).

There has been significant change in the public sector towards being more performance-driven and providing challenging positions in terms of work content. The psychological contract associated with traditional public employment has been fundamentally challenged by the implementation of the 'new public management' and its associated change in the status of personnel (Horton, Hondeghem \& Farnham, 2002). The employment conditions offered by the public employer, as well as expectations in terms of behaviour and performance, are beginning to mirror those of private organisations. 'Out of concern to be a competitive, choice employer, public employment is threatened by appearing to be losing the advantages that for a long time characterised its specific attractiveness including job security, less stressful pace of work, advancement possibilities and so on' (Horton et al., pp. 25-26). It therefore becomes a business imperative for the public organisation to have a well-informed EVP to retain targeted groups of employees. In answering the main question of the study, namely what the key factors are that influence professional and management employees to remain employed in local government, the factors found will inform the understanding of an EVP in the South African local government context.

In an attempt to deal with this challenge it is of importance for a public service organisation to determine what the factors are that contribute to both the attraction and retention of skilled and professional employees. A case in point is the research conducted by the Hay Group, which has shown that $30 \%$ of the variability in non-public business performance is due to work climate; in other words, the way individuals feel at work affects their discretionary effort (Robbins, Odendaal \& Roodt, 2001; Saratoga Institute, 2005). Fifty to seventy per cent of the work climate is a function of leadership and management style (Saratoga Institute, 2005). Organisations must create a compelling place to work for their employees, i.e. a working environment that is supportive of ideas, innovation and personal growth and development (Ulrich, 1998)

An important distinction in EVP attributes is those things of value to employees that an organisation is perceived to offer, which serves to attract potential employees, while a completely different set serves to retain employees (Fairhurst, 2007).
Fairhurst (2007) suggests that potential employees tend to judge employers on EVP attributes such as remuneration, location, perceived career opportunities and stability of the organisation. He maintains that existing employees tend to look at much deeper attributes, such as how respectfully they are treated, how well the jobs match their own particular interests and the quality of their managers. The research findings indicate that organisations that are perceived to be delivering on the EVP promises enjoy substantially higher levels of employee commitment. This results in improved performance and retention, where the probability of an individual leaving could be reduced by as much as $87 \%$ (Fairhurst, 2007).

As indicated above, there is a clear distinction between the factors that attract employees and those that retain them. However, these factors are generally combined in studies on retention. Studies combining these factors will be discussed first, followed by those that focus on retention individually.

\section{Attraction and retention factors}

Important attractors and retainers of high-end skills include effective management of performance and diversity, learning pathways, management style, stretch assignments, work/ life balance, recognition, non-monetary rewards, high job involvement, job security and stability, physical working conditions, flexible pay and employment practices, autonomy personal development, award schemes, and a caring workplace (Arden, 2006; Bell, 2005; Horwitz, 2007; Marriott, 2001; Robbins et al., 2001; Saratoga Institute, 2005).

Compensation plays a key role in the attraction, retention and motivation of employees (Swanepoel, Erasmus, Van Wyk \& Schenk, 2003). When focusing on the retention of scarce and highly marketable specialist skills of knowledge workers, the following can be identified as priority needs:

- Opportunities for development in an employees' field of expertise

- Freedom to plan and execute work independently

- Growth potential of the industry

- Progressive leadership that allows initiative and sharing in the profits of the organisation.

In terms of attracting and retaining high-end skills, four categories of issues were found by the Corporate Leadership Council to constitute a compelling job offer for scarce skills. The four attractors and retainers are indicated in Table 1.

The four factors cover many of the indicators discussed in the text thus far. Furthermore, work/life balance factors are also cited as retention factors by DeMarco (2007) and Gillis (2007).

In a study on the value proposition of employment, Britton et al. (1999) constructed a model of the rewards of work that lead to attraction and retention. The model contains the following five groupings of factors: 


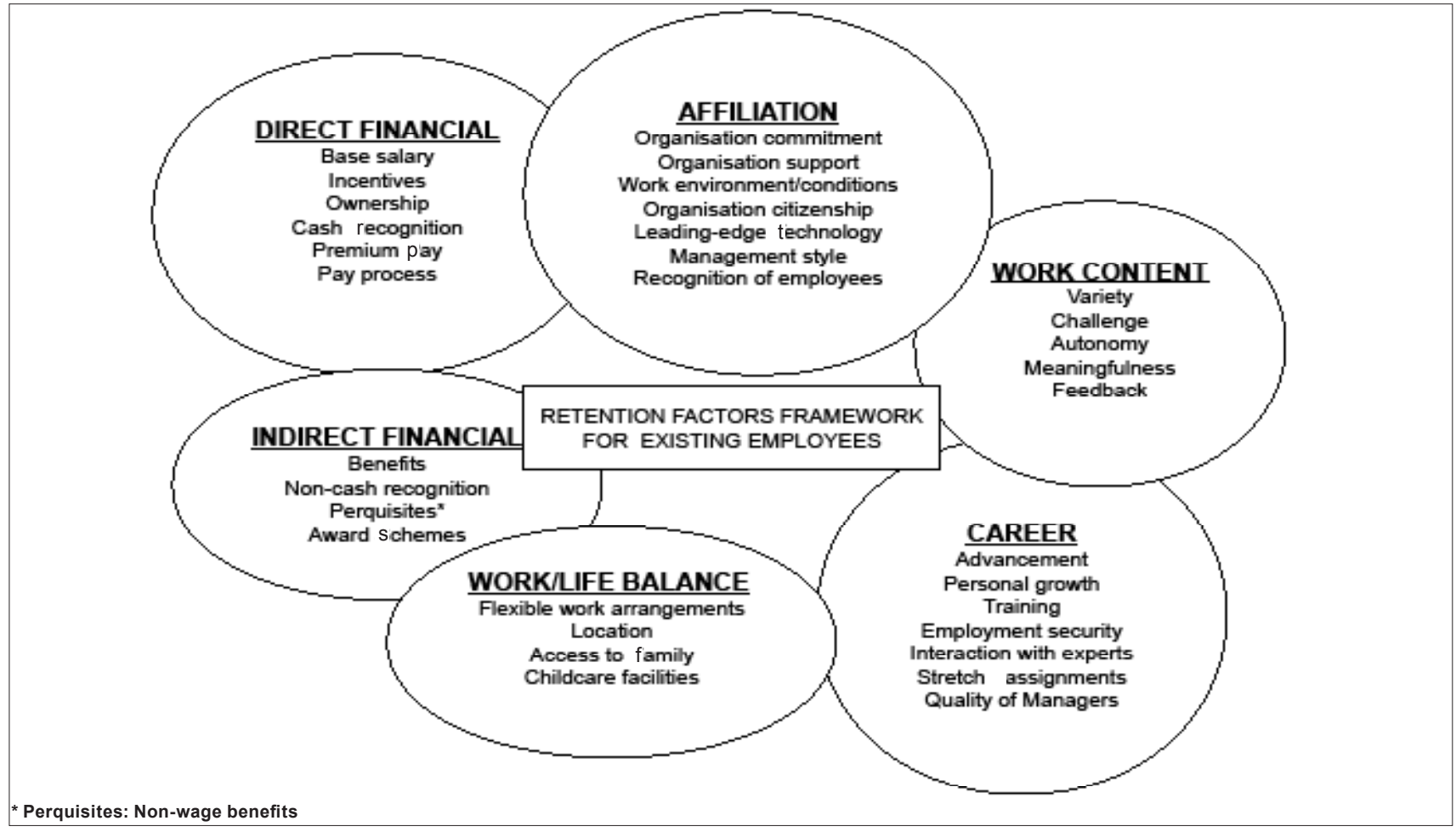

FIGURE 1

Retention Factors Framework for Existing Employees (adapted from Britton et al., 1999)

- Affiliation

- Direct financial

- Indirect financial

- Career

- Work content.

The Britton et al. model was used as a framework by means of which all the previously stated literature was integrated, and is presented in Figure 1.

\section{Retention factors}

Research conducted on the state of the South African training industry, in which respondents were human resources managers and training managers in all nine South African provinces covering 23 of the 25 Sector Education and Training Authorities (SETAs), indicated that management style is the most prominent employee retention factor in South Africa (Meyer, 2005). Effectively, $65 \%$ of those surveyed indicated this to be true. This is echoed by Isabel (2007), who found the same. While training can play a positive role in empowering staff with the necessary knowledge and skills, the consequent challenge would be to retain the employees (Meyer, 2005). For the purposes of this study, leadership is seen as management style, as probed by the Meyer (2005) study. Retention factors concluded in a study by Sutherland (2004) include job satisfaction, organisational commitment, intention to leave, organisation culture, health benefits, communication of strategy, independent work, relationship with immediate boss, honesty of management, individualising of the job, encouragement of social ties and perceived employability.

Flexible work arrangements have been used for more than a decade as a way of retaining valued employees. However, this is a short-term fix (Maitland, 2007). Instead, employees should be encouraged to choose from a menu of options in the following four areas:

- Pace of career progress (ranging from accelerated to decelerated)

- Workload (from full to reduced)

- Location and schedule (from not restricted to restricted)
- Role (from leader to individual contributor) (Maitland, 2007).

The use of these four options formalises what some organisations already practise (Hamel, 2007). Employees have continual conversations with supervisors and team members regarding their specific needs, and many executives accelerate or decelerate their careers accordingly (Maitland, 2007).

The re-emergence during the last two decades of performancerelated pay as a means of retaining employees is grounded in the notion that individuals in the 21st century are driven predominantly by money (Frederick, 2001). However, the 2007 Executive Intelligence Unit (EIU) Corporate Network Survey indicated that raising pay to above-market rates was only the fourth most effective strategy to retain key staff (Horwitz, 2007). While remuneration is important, though sometimes overemphasised compared to other factors, it is more effective to focus on non-financial factors (Bell, 2005). Employers should offer value captured in an EVP, which is the same strategy used to attract and retain customers. 'Just as our customers know that value transcends price, now we must offer our employees value beyond just compensation' (Marriott, 2001, p. 18).

Three retention strategies are suggested to effectively deal with the Generation X work group, i.e. those born between 1964 and 1977 (DeMarco, 2007). Firstly, communication is vital. This includes feedback, group communication, corporate communication and employee surveys. Secondly, employers should consider issues such as supervision in terms of the manager building the team, performance management and the development of individuals; and thirdly, attention should be paid to the matter of generational interest. Employees want to know that they are valued and important. Employees also cite a work/life balance as crucial (DeMarco, 2007; Gillis, 2007). Generational applicability was not probed in this study.

Although the myriad of literature reviewed in the text was derived from a combination of corporate sources, South African as well as international, there is still an absence of South African local government frameworks. 
Retention Factors Framework for Existing Employees The Retention Factors Framework for Existing Employees (Figure 1) includes all the literature referred to in this article. In this section, the meaning and interpretation of each of the factor groupings is given. The Direct Financial Grouping constitutes tangible pay-related factors, for example bonus payment as part of incentive pay. The Indirect Financial Grouping consists of factors such as benefits related to security and saving, medical aid funding, pension or provident fund benefit, and other noncash recognition or benefits by way of employee award schemes. The Work/Life Balance Grouping contains factors related to the amount of flexibility allowed with work arrangements, the convenience associated with the location of work and access to family and childcare facilities.

The Career Grouping relates to an individual's future position, and is associated with factors such as personal growth, career advancement, opportunity for and access to training, as well as employment security. Additional factors included are the availability of interaction with experts, receiving stretch assignments and the quality of management. The Work Content Grouping relates to an individual's current position, and includes factors such as variety of work, the degree to which the individual is challenged, and the degree to which the individual can work autonomously and perform meaningful work. Affiliation as a grouping is largely about being part of a supportive organisation, with a good working environment and/or working conditions that include leading edge technology and a progressive management style that recognises employee contributions.

The purpose of conducting this study was to understand what the key factors are that influence professional and management employees to remain employed in a local government organisation. From these factors a well-informed EVP for the existing employees can be designed. The EVP serves as a criterion against which the organisation can benchmark all human resource retention interventions and outcomes. The question posed to participants was therefore: 'Why did you choose to remain employed at your organisation?' The question was framed so that the positive retention factors could be determined, instead of those factors that negatively contributed to staff turnover. The semi-structured interview questionnaire was aligned to the Retention Factors Framework for Existing Employees. The questionnaire therefore prompted responses from the participants in terms of how the direct financial, indirect financial, work content, career, work-life balance and affiliation factors contributed to them being influenced to remain employed in the local government organisation.

\section{Research approach}

\section{RESEARCH DESIGN}

A qualitative, empirical, analytical research paradigm was adopted, as the study aimed to provide an in-depth description of a group of people through analysing responses received from semi-structured interviews (Mouton, 2001). This paradigm was adopted in order to understand the retention factors important to the research participants in their natural setting, which aided in establishing a rapport with the participants. The participatory nature of the design minimises suspicion and distrust of the study with a concomitant increase in trust and credibility (Mouton, 2001). A limitation could be that, due to the emphasis being on naturalistic forms of inquiry, it is difficult to evaluate the outcomes perhaps as systematically and rigorously (Mouton, 2001). The study was exploratory, and was aimed at expanding on existing baseline literature, in an attempt to integrate existing knowledge into a framework without limiting the framework to the existing literature alone. Although a number of studies on attraction and retention factors existed, there was no framework that integrated their findings for local government. It was the researchers' opinion that such an integrated framework would contribute to understanding factors that retained employees in an organisation. The framework would, however, need to be expanded without limiting it to the pre-identified categories found in the literature. Such expansion of knowledge was only possible through qualitative means (Denzin \& Lincoln, 2008). Since an intensive literature study was conducted before data collection commenced, a modernist approach was followed, which relied on a framework representing the integrated literature.

The researchers assumed an observer role although they realised that they could not be fully removed from the interaction with participants. Furthermore, the analysis of data was both objective through comparison against the framework and subjective by thematic analysis. The interpretation of the interview data was done inductively (Braun \& Clark, 2006).

\section{Research strategy}

A case study strategy was followed after completion of the literature study. Other empirical research strategies, for example participatory research, action research, surveys, experimental designs, evaluation research, secondary data analysis, content analysis and so on were found not to be appropriate for this research approach. The focus was on the professional and management grouping of employees at a public service organisation (Welman \& Kruger, 1999). The themes derived from each individual participant (unit of analysis) were integrated into the group's findings. These findings were compared with and integrated into the literature framework. This strategy was in line with the modernist approach that was followed where a universal result was generated for the case participants.

\section{Research method}

A theoretical framework was used to deduct and compare data (Welman \& Kruger, 1999). This framework was referred to as the Retention Factors Framework for Existing Employees, as explained in the literature review, which served as what we know to be true of retention factors. Semi-structured interviews were conducted. Interview data were compared against the framework, resulting in comparisons against predetermined and precisely defined factors, as well as an indication of the frequency of factors found - all of which are characteristic of thematic analysis (Braun \& Clark, 2006). Results were derived through thematic analysis, which involved the identification and analysis of themes and patterns of similarity (Braun \& Clark, 2006).

Qualitative data sources included semi-structured interviews - an interview guide based on the literature framework - as well as the researcher's impressions and reactions, contained in interview notes (Myers, 1997). The motivation for undertaking qualitative research was that richness of data could be obtained by asking additional questions to further probe answers, and to accommodate the exploratory nature of the study (Denzin \& Lincoln, 2008). Participants were also requested to rate the importance of the themes, as the researcher was interested in determining whether certain themes were more important than others, as those themes would be of greater importance in informing the organisation's EVP.

\section{Research setting}

The organisation chosen for the research study was a local government organisation in South Africa. Data collection took place in December 2007, a period when local government managers were employed on a non-permanent contract basis. The collection, analysis and verification of data were completed within six months.

\section{Entrée and establishing researcher roles}

The main researcher was employed by the local government organisation at the time when the study was undertaken. Although this was the case, the researchers did not personally 
know any of the participants. Permission was sought from the Director of Human Resources to carry out the study. Permission was granted, as the results of the study would be beneficial to the management tasked with the attraction and retention of professional and management employees. Information was kept confidential, and participants remained anonymous.

\section{Sampling}

Potential research participants were identified on the basis of the length of time they were employed within the organisation, their level of seniority, a spread of functions and their job performance rating. As there were various participants who met the performance and tenure criteria, purposive sampling was used in terms of distribution of departments or function, race, gender, age and performance (Punch, 2005). This involved sampling in a deliberate manner in order to be inclusive, with a specific purpose in mind, namely to understand what the targeted grouping of employees deemed important as retention factors.

The research participants were management and professional employees from a local government organisation, specifically those who had remained with the organisation for longer than six years. A six-year period appeared to be a reasonable benchmark for tenure, based on the P-E Corporate Services Survey conducted in 2001 (Sutherland, 2004). Of the 700 South African companies surveyed, $67 \%$ of the sample of senior management leavers had fewer than six years of service. For middle management and skilled staff, $40 \%$ of leavers had fewer than six years of service. Therefore, six and more years of service serves as a benchmark for solid tenure in the South African context. The participants included a span of seniority level such as executive directors, directors, deputy directors, managers and other professional employees who had at least a national diploma or degree. Marketable participants were selected in order to pre-empt the possibility that they were unemployable in other contexts, and therefore not able to move to other organisations. The ages of the research participants varied with two participants under 45 years, one participant between 45 and 49 years of age, and seven participants older than 50 years.

The use of the participants' performance-management scores as part of the selection criteria ensured that value-adding employees were targeted. For each of the participants a minimum overall performance rating of $80 \%$ for at least the past two financial years was required. This approach also assisted in countering potential bias in the case of the seven participants older than 50 years, as it could be argued that this group of individuals may choose not to seek alternative employment, irrespective of adverse conditions at work. Semi-structured interviews were conducted with a total of 10 research participants. At this point data saturation occurred, where responses with similar themes were being identified.

\section{Data-collection method}

The research method enabled the development of a framework through an in-depth literature review. The framework also informed a set of questions that were asked during semistructured interviews. The semi-structured interview as a datacollection tool was considered a good way of probing people's perceptions and the meaning they attached to reality (Punch, 2005).

During the interview the process was explained, and the interviewee was informed that the researcher would make notes, and told that the interview would also be audio-recorded. Interviews commenced with interviewees being asked two open-ended questions, which were 'Why did you choose to join the organisation?' and 'What factors have caused you to remain with the organisation for more than six years?' Information was clarified and refined by asking further probing questions such as 'Was remuneration a key factor in your joining the organisation, or was it a factor that influenced you to remain with the organisation?' The interviewee was also asked whether the factors that he or she mentioned were possibly push or pull factors. Push factors refer to factors that would make the interviewee consider leaving the organisation, and pull factors are those factors that contribute to retaining the employee. The participants were also requested to rate the 25 retention factors, as identified in the literature framework, with regard to their importance, on a scale from one to five, where one was not important and five was very important. Ten interviews were concluded before transcription and analysis took place. Results were verified with interviewees to ensure alignment with what they had actually meant.

\section{Data analysis}

Data analysis is the process of bringing order, structure and meaning to a mass of collected data (Marshall \& Rossman, 1995). The analysis involved searching for statements that supported the factors indicated in the Retention Factors Framework for Existing Employees. Common themes and patterns were identified, tracked and rated for importance among the participants. Research participants were requested to rate the 25 factors that were identified in the above framework, in order of their importance to them personally. The rated data were summated, and the overall top factors were identified.

Data reduction occurred continually throughout the analysis. In the early stages it occurred through the editing, segmenting and summarising of data by linking the data to the retention factors. In the middle stages it was done through coding and memoing, for example Direct Financial, Indirect Financial, Affiliation, Work Content, Career and Work/Life Balance. The coding was done by hand; no computer-aided system was used. This stage also involved finding themes, clusters and patterns. In the later stages reduction occurred through conceptualising and explaining, since developing abstract concepts is a way of reducing data without significant loss of information (Punch, 2005). The themes were ranked and tested against the existing literature and the Retention Factors Framework for Existing Employees.

\section{Strategies used to ensure quality research}

The manner in which rigour was maintained was by allowing participants to guide the inquiry process, as suggested by Chiovitti and Piran (2003). This was done through initially using open-ended questions, checking the research participants' responses against the theory, using the research participants' actual words in findings, where appropriate, articulating the researcher's personal views and insight about the problem being explored specifically at the onset of the interview, specifying the criteria built into the researcher's thinking such as the literature framework and research design, specifying how and why participants were chosen, delineating the scope of the research, and describing how the literature related to each category that emerged through the research findings. The guidelines provided by Chiovitti and Piran (2003) were adhered to so as to ensure that rigour in terms of credibility, auditability and fit was maintained throughout the research process. The participants were unknown to the researchers. This aided in avoiding researcher bias. Furthermore, a second researcher reviewed and adjusted the coding, which also assisted in limiting bias.

\section{Reporting}

A modernist approach was adopted for the purposes of reporting the findings of this research study. This suggests that the researchers looked for probabilities or support for arguments concerning the likelihood that a conclusion in fact applies in the specific situation (Denzin \& Lincoln, 2008). Therefore, reporting occurs through scientific as well as realist tales (Sparks, 2002). To comply with realist tales, the results of this study contain quotations from participants that describe and substantiate the findings. The findings were then compared to the literature framework. 
TABLE 2

Themes as deduced from the responses of research participant

\begin{tabular}{ll}
\hline THEMES & GROUNDEDNESS \\
\hline 1. Job aligned with personal meaning/passion & 90 \\
2. Direct financial & 39 \\
3. Opportunities for development & 38 \\
4. Indirect financial & 23 \\
5. Work environment/content & 22 \\
6. Sense of achievement & 19 \\
7. Autonomy & 18 \\
8. Promotion & 15 \\
9. Recognition & 15 \\
10. Close proximity to work & 15 \\
11. Teamwork & 14 \\
12. Flexibility & 12 \\
13. Trust & 12 \\
14. Work/life balance & 12 \\
15. Supportive of balance & 11 \\
16. Sense of security & 7 \\
\hline
\end{tabular}

\section{FINDINGS}

The responses obtained through the semi-structured interviews are illustrated in Table 2 in order of groundedness (frequency at which the theme was indicated). In a final step these themes were compared against the theoretical framework (Table 3).

Sixteen themes were identified from the consolidated responses received from the research participants. These themes were the reasons for remaining in the employ of the organisation. Groundedness therefore indicated theme frequency, i.e. the number of quotations to which a theme was applied, or the number of quotations linked to a specific theme (Muhr \& Friese, 2004). Groundedness in this instance serves to clearly distinguish the key themes highlighted by the research participants. It is evident from Table 2 that a key retention driver for this grouping of employees was the theme of Job Aligned with Personal Meaning or Passion. This driver was mentioned 90 times. An example of the job being aligned to personal meaning is illustrated by the following participants' statements:

'I believe that working for local government would place me closer to communities in addressing their service delivery issues

as well as

'I realised that my passion was more focussed at Community Health as opposed to health-rendering in a hospital setting'

The participants indicated that they remained with the organisation due to the alignment between the job that they were performing and that which was meaningful to them personally, or what they were passionate about. Another example cited in the interviews is the following:

'... the fact of being a health worker ensures my commitment - I will exercise the same level of commitment as a health practitioner, irrespective of where I practice'

The second most grounded theme was Direct Financial, which appeared only 39 times compared to 90 times for Job Aligned with Personal Meaning or Passion. The themes Direct Financial and Opportunities for Development appeared 39 and 38 times respectively. This seems to indicate that the salary component and the development opportunities were important reasons to remain employed with this organisation. An example of Direct Financial being an important factor is where a participant stated the following:

'Financial reward is certainly one of the factors that contribute to my remaining with the organisation

When asked how career development opportunities had influenced their decision to remain with the organisation, a participant stated:

'Substantially, I would say at least $60 \%$ of my decision to remain was the training and development opportunities available'

Compared to the themes that followed, the first three themes of Table 2 were the most emphasised. While this did not necessarily indicate greater importance, it did highlight key areas of common retention factors among the participants.

The themes Promotion, Recognition and Close Proximity to Work were mentioned 15 times, while Flexibility, Trust and Work/Life Balance were mentioned 12 times in the participants' responses. This indicated that these were also factors that influenced this grouping of employees to remain with the organisation. While these factors were not mentioned as frequently, they were clearly important, as almost all ten participants mentioned that a good balance was required, for example in terms of work/life balance. The themes Teamwork and Sense of Security appeared 14 and 7 times respectively, in comparison with the 90 times of Job Aligned with Personal Meaning or Passion. In terms of the number of times mentioned, the lowest scoring theme is Sense of Security. It was mentioned only seven times. This could be as a result of many of the research participants being on fixed-term contracts, and knowing that their contracts were dependent on their performance. Where an individual's performance was in line with what was expected of him or her, there was a greater probability of his or her contract being renewed. These were high-performing employees, which could be the reason why Sense of Security was not mentioned as often as some other themes.

Table 3 provides a comparison between the themes derived from the data and the theoretical framework. The common themes that were identified through the interviews conducted with the research participants were juxtaposed with the Retention Factors Framework for Existing Employees. It is clear from Table 3 above that the majority of themes that were identified related to the Work Content Grouping, which is consistent with the analysis highlighted in Table 2 . There are four themes related to Affiliation and Work/Life Balance, which is second to that of the Work Content Grouping, which has five associated themes. The Career Grouping has three associated themes, namely Opportunities for Development, Promotion and Sense of Security. There are themes that relate to more than one retention factor, for example Recognition, which is derived through affiliation with the organisation, as well as through the actual work content.

The research participants also indicated direct financial and indirect financial rewards as factors that had caused them

TABLE 3

Comparison between the identified themes and theoretical framework

\begin{tabular}{|c|c|c|c|c|c|c|}
\hline THEMES & DF & IF & A & WC & C & WLB \\
\hline $\begin{array}{l}\text { 1. Job aligned with personal } \\
\text { meaning/passion }\end{array}$ & & & & $\mathrm{x}$ & & \\
\hline 2. Direct financial & $x$ & & & & & \\
\hline 3. Opportunities for development & & & & & $x$ & \\
\hline 4. Indirect financial & & $x$ & & & & \\
\hline 5. Work environment/content & & & $\mathrm{x}$ & $\mathrm{x}$ & & \\
\hline 6. Sense of achievement & & & & $\mathrm{x}$ & & \\
\hline 7. Autonomy & & & & $\mathrm{x}$ & & \\
\hline 8. Promotion & & & & & $x$ & \\
\hline 9. Recognition & & & $\mathrm{x}$ & $\mathrm{x}$ & & \\
\hline 10. Close proximity to work & & & & & & $x$ \\
\hline 11. Teamwork & & & $\mathrm{x}$ & & & \\
\hline 12. Flexibility & & & & & & $x$ \\
\hline 13. Trust & & & $\mathrm{x}$ & & & \\
\hline 14. Work/life balance & & & & & & $\mathrm{x}$ \\
\hline 15. Supportive of balance & & & & & & $\mathrm{x}$ \\
\hline 16. Sense of security & & & & & $\mathrm{x}$ & \\
\hline $\begin{array}{l}\overline{W C}-\text { Work content } \\
\text { A-Affiliation }\end{array}$ & $\begin{array}{l}\text { life } \\
\text { nand }\end{array}$ & & & $\overline{\text { areer }}$ & fin & \\
\hline
\end{tabular}


to remain with the organisation. Examples of these were the following:

'Being attracted through receiving a higher salary' as well as '... with the introduction of the performance-management system my salary increases have increased my remuneration quite high [sic], which sort of forces you to go the extra mile'

'And I receive the normal increases as any permanent employee and through these increases my benefits portion also increase [sic]'

Push and pull factors could not be clearly defined, due to the fact that some participants viewed certain factors as push factors, while other participants viewed them as pull factors. Salary could be a push factor to employees who are not on the performance-linked bonus scheme, while salary was a pull factor to those who were indeed on the performance-linked bonus scheme. Participants also indicated that they might leave if offered a better salary (push). However, the job would have to be challenging, and something that they were passionate about (pull), and they would therefore not be prepared to leave purely for more money, hence there were no clear push or pull factors identified.

Each participant's rating of the individual factors was consolidated, and the scores were then ranked in order of their importance to the particular participant (refer to Table 4). Challenging and meaningful work that related to the theme Job Aligned to Personal Meaning or Passion was ranked the most important factor. The majority of the factors scored high, around 40, with only Flexible Working Arrangements, Performance Bonus Pay, Employee Benefits, Non-cash Recognition and Access to Childcare Facilities scoring below 40. There were no statements that contradicted the framework.

\section{DISCUSSION}

The objective of the study was to answer the main question, namely what the key factors were that influenced professional and management employees to remain employed in the local government organisation. The findings, as stated above, have largely answered the question of what the key factors were for the professional and management grouping of employees that are in the maintenance phase of their careers. The findings also suggested implications for the organisation. These implications are discussed in this section.

The theme Job Aligned with Personal Meaning or Passion was expressed in various ways by the research participants - from being able to influence policy and making a difference in terms of service delivery to being able to serve the ruling political party. The researchers realised that there was a myriad of interpretations of personal meaning as expressed by the research participants, but that in essence they were expressing their passion. The fact that seven of the ten respondents were over 50 years of age might account for the very high support for the theme Job Aligned with Personal Meaning or Passion. This is in line with the kaleidoscope career theory of Mainiero and Sullivan (2006), which states that men and women seek authenticity, including passion, in the middle to late stages of their careers. This finding has implications for people in management who are tasked with the recruitment and retention of professional and management employees in the organisation, as suggested by Ingham (2006).

Over and above the competency-based interviews when hiring new employees, the interviewing process for future management and professional employees should consider the employee's interests, and whether a position will be aligned with that individual's personal meaning or passion. Specific questions must be asked to determine the candidate's ability to fit into the position being offered. The working environment needs

TABLE 4

Retention factors rating

\begin{tabular}{|c|c|c|c|c|c|c|c|c|c|c|c|c|}
\hline No. & FACTOR & R 1 & R 2 & R 3 & R 4 & R 5 & R 6 & R 7 & R 8 & R 9 & R 10 & TOTAL \\
\hline 1. & Challenging and meaningful work (WC) & 5 & 4 & 4 & 4 & 5 & 4 & 5 & 5 & 5 & 5 & 46 \\
\hline 2. & Work variety (WC) & 5 & 4 & 4 & 4 & 5 & 5 & 5 & 5 & 4 & 5 & 46 \\
\hline 3. & Employability (C) & 5 & 4 & 4 & 4 & 5 & 4 & 5 & 5 & 4 & 5 & 45 \\
\hline 4. & Access to family (WLB) & 5 & 5 & 5 & 5 & 5 & 5 & 3 & 5 & 2 & 5 & 45 \\
\hline 5. & Working autonomously (WC) & 5 & 5 & 4 & 3 & 5 & 5 & 4 & 5 & 3 & 5 & 44 \\
\hline 6. & Interaction with experts $(\mathrm{C})$ & 5 & 4 & 4 & 3 & 4 & 5 & 5 & 5 & 4 & 5 & 44 \\
\hline 7. & Quality of managers $(C)$ & 5 & 5 & 4 & 3 & 5 & 5 & 4 & 5 & 3 & 5 & 44 \\
\hline 8. & Sense of belonging in organisation (A) & 5 & 4 & 4 & 3 & 5 & 5 & 5 & 5 & 3 & 5 & 44 \\
\hline 9. & Values congruency $(\mathrm{A})$ & 5 & 3 & 4 & 3 & 4 & 5 & 5 & 5 & 5 & 5 & 44 \\
\hline 10. & Career development - personal growth (C) & 5 & 3 & 4 & 4 & 5 & 4 & 5 & 5 & 5 & 3 & 43 \\
\hline 11. & Stretch assignments $(\mathrm{C})$ & 5 & 4 & 4 & 4 & 4 & 4 & 5 & 5 & 3 & 5 & 43 \\
\hline 12. & Leading edge technology (A) & 5 & 4 & 4 & 3 & 5 & 5 & 4 & 5 & 3 & 5 & 43 \\
\hline 13. & Management style (A) & 5 & 4 & 4 & 2 & 5 & 5 & 5 & 5 & 3 & 5 & 43 \\
\hline 14. & Basic pay (DF) & 5 & 5 & 5 & 4 & 5 & 4 & 3 & 5 & 3 & 3 & 42 \\
\hline 15. & Job security $(C)$ & 5 & 5 & 4 & 4 & 5 & 4 & 3 & 5 & 4 & 3 & 42 \\
\hline 16. & Work environment/ conditions (A) & 5 & 4 & 3 & 2 & 5 & 4 & 5 & 5 & 4 & 5 & 42 \\
\hline 17. & Training opportunity (C) & 5 & 3 & 5 & 3 & 4 & 4 & 5 & 5 & 4 & 3 & 41 \\
\hline 18. & Location of organisation (WLB) & 5 & 2 & 5 & 4 & 5 & 5 & 4 & 5 & 3 & 3 & 41 \\
\hline 19. & Balance between personal and family life (WLB) & 3 & 5 & 5 & 3 & 4 & 4 & 4 & 5 & 3 & 5 & 41 \\
\hline 20. & Feedback (WC) & 5 & 3 & 3 & 2 & 4 & 5 & 5 & 5 & 5 & 3 & 40 \\
\hline 21. & Flexible working arrangements (WLB) & 5 & 2 & 3 & 3 & 5 & 5 & 5 & 5 & 2 & 3 & 38 \\
\hline 22. & Performance bonus pay (DF) & 5 & 5 & 5 & 1 & 3 & 4 & 5 & 5 & 3 & 1 & 37 \\
\hline 23. & Employee benefits (IF) & 4 & 1 & 5 & 4 & 5 & 4 & 3 & 4 & 4 & 3 & 37 \\
\hline 24. & Non-cash recognition (IF) & 4 & 1 & 5 & 2 & 1 & 4 & 3 & 4 & 1 & 3 & 28 \\
\hline 25. & Access to childcare facilities (WLB) & 1 & 4 & 1 & 1 & 3 & 3 & 2 & 3 & 2 & 3 & 23 \\
\hline
\end{tabular}

WC - Work content WLB - Work/life balance C - Career

A-Affiliation $\quad$ DF - Direct financial $\quad$ IF - Indirect Financial 
to be conducive to allowing employees to become involved in matters they are passionate about. Employees can, for example be allowed and encouraged to volunteer for projects where their interests lie, so as to feed their interests and matters they are passionate about, thereby retaining them. This will assist in creating a compelling place to work - a working environment that is supportive of employees' ideas, innovation and personal growth and development (Ulrich, 1998). This, however, must then be linked to the organisation's remuneration and performancemanagement system, as a holistic approach must be adopted. Part of the findings highlighted direct financial reward as being important to respondents, indicating that the cash component is an important factor. Employees want to be recognised for their efforts, as there appears to be a desire for balance between what they give and what they receive, as described by Fairhurst (2007). Rewarding individual performance will therefore further enhance the organisation's EVP (Swanepoel et al., 2003).

The themes Direct Financial and Opportunities for Development appeared 39 and 38 times respectively. These responses suggest that this grouping of employees has had increases in salaries over time, and has had opportunities to develop. It furthermore appears that the career progression was matched with salary increases. Career development and progression are retention factors for this grouping of employees. This indicates that career and succession planning must form part of the organisation's EVP and retention strategy (Isabel, 2007; Meyer, 2005). This again should be linked to the organisation's reward and performancemanagement systems.

When moving down the list of groundedness of themes, the themes Indirect Financial and Work Environment/Content appeared 23 and 22 times respectively during the 10 interviews. The aspect of work content is also closely linked to the highest scoring theme (Job Aligned with Personal Meaning or Passion), as personal meaning largely relates to the individual's work content. This suggests that the work performed by the groupings of employees who were targeted must be linked to what they are passionate about. It is also important that the fact that the organisation does offer its employees a value proposition, and that there is a retention strategy being put in place to keep their valued employees, must be effectively communicated to employees. This suggests that employers need to brand their value proposition to employees, which would serve to remind employees of the benefit they derive from being associated with the organisation. Existing employees are likely to consider more insightful attributes such as how respectfully they are treated, how well the jobs on offer match their own particular interests and the quality of their managers. The theme Access to Childcare Facilities was ranked the lowest by the research participants. This could be due to the fact that the majority of the participants were older than 50 years of age, and access to childcare facilities therefore was no longer an area of need to them. This area should, however, always be probed when developing an EVP to cater for the overall needs of the targeted employees.

\section{Conclusion}

A systematic approach was adopted in undertaking this study - from identifying the problem, understanding the subject matter by way of a literature review, planning the approach and methodology to executing the study and writing up the findings. The article consolidates much of the literature on retention factors, and serves to add to the existing body of knowledge by way of the research findings. There is a clear link between the research study and the literature reviewed, highlighting what the targeted grouping of employees deems important. This in turn would inform the organisation's EVP and any other retention initiative that the organisation would want to embark on. The factor Job Aligned with Personal Meaning or Passion is clearly important to this grouping of employees, and should form part of the attraction and retention strategy for the organisation. The other factors such as Direct Financial, Indirect
Financial, Opportunities for Development and Work Variety also seem to be important to this grouping of employees. Part of the organisation's EVP should be to empower employees to influence service delivery and make a meaningful contribution to the local communities while being challenged through a wellstructured performance-management system. By understanding what the targeted grouping of employees deems key retention factors, the organisation will be in a much better position to devise responsive retention strategies based on their EVP, as well as to implement practices that are likely to be more successful at retaining the targeted group of employees. Employees also need to be made aware of initiatives that the organisation has in place, or is currently implementing, so that they may feel valued, and will want to remain with the organisation. In some instances it is the communication to employees regarding the organisation's offerings that must be improved, and not necessarily the provision of specific attributes (Birt, Wallis \& Winternitz, 2004). Another workplace implication is that managers should have an understanding of what their employees attach personal meaning or passion to. This can be achieved by managers engaging with their employees through structured employee-engagement sessions that should be facilitated by human resources practitioners. The information gained from employees through these sessions will enable managers to create the environment and flexibility within the organisation for employees to have their jobs aligned with what they attach personal meaning or passion to.

\section{Future research}

Possible future research could entail comparing this framework with studies investigating employer attractiveness in terms of value propositions. Research on standardising retention factors that could inform the EVP of local government in South Africa would be useful in the struggle to retain managerial skills.

\section{Limitations}

This study was conducted in a local government setting in which the unit of analysis was limited to professional and management employees in the maintenance phase of their careers. While the literature framework assists in the development of theory, the results can only be generalised to this grouping of employees. Furthermore, the identification of push and pull factors could not be achieved. This indicates that, although a framework to inform the universal application of retention factors is helpful, the unique needs of individuals ensure that it should not be interpreted without qualitative input. The external influence of politics, as local government selects candidates that show allegiance to the ruling party, was not probed in the study. Political stance may have a bearing on retention factors but does not negate the usefulness of this study's findings. Although global private sector studies have been referenced, this study has particular relevance to the local government organisations that also benchmark themselves internationally against private sector surveys, such as that of the Saratoga Institute (2005).

\section{REFERENCES}

Arden, C. (2006). How to get your employment brand to work. Management, July 4. Retrieved August 27, 2007, from http:// findarticles.com

Batt, R. (2002). Managing customer services: Human resource practices, quit rates and sales growth. Academy of Management Journal, 45, 587-597.

Bell, A. (2005). The employee value proposition redefined. Strategic HR Review, 4(4), 3.

Birt, M., Wallis, T., \& Winternitz, G. (2004). Talent retention in a changing workplace: An investigation of variables considered important to South African talent. South African Journal of Business Management, 35(2), 25-31.

Braun, V., \& Clark, V. (2006). Using thematic analysis in psychology. Qualitative Research in Psychology, 3, 77-101.

Britton, P.B., Chadwick, S.J., \& Walker, T. (1999). Rewards of work. Ivey Business Journal, 63(4), 46-53. 
Buckingham, M., \& Clifton, D.O. (2001). Now discover your strengths. Croydon: Bookmarque.

Byham, W.C., Smith, A.B., \& Paese, M.J. (2002). Grow your own leaders, develop and retain leadership talent. Upper Saddle River: Prentice-Hall.

Chiovitti, R.F., \& Piran, N. (2003). Methodological issues in nursing research: Rigour and grounded theory research. Journal of Advanced Nursing, 44(4), 427-435.

Corporate Leadership Council (2002). The ageing workforce: Retention and knowledge management. Retrieved October 14, 2008, from www.corporateleadershipcouncil.com

DeMarco, D. (2007). CSI: The employee retention mystery. Supervision, 68(6), 8-11.

Denzin, N.K., \& Lincoln, Y.S. (2008). The landscape of qualitative research. (3rd edn.). Thousand Oaks: Sage.

De Villiers, R. (2006). Alumni talent: How losing the retention battle can help win the talent war. Civil Engineering, 14(1), 15.

Fairhurst, D. (2007). Don't lose them, schmooze them. Human Resources, January 10, 10.

Frederick, D. (2001). Motivating staff. Credit Management, February, 34-36.

Gillis, T.L. (2007). Employee communication is no small wonder. Communication World, 24(5), 28-30.

Hamel, G. (2007). The future of management. Boston: Harvard Business School.

Heger, B.K. (2007). Linking the employment value proposition (EVP) to employee engagement and business outcomes: Preliminary findings from a linkage research pilot study. Organisational Development Journal, 25(2), 121-134.

Horton, S., Hondeghem, A., \& Farnham, D. (2002). Competency management in the public sector. Amsterdam: IOS Press.

Horwitz, F. (2007). Retention strategies critical in a global market shortage of skilled workers. Cape Town: UCT.

Ingham, J. (2006). Closing the talent management gap. Strategic HR Review, 5(3), 20-24.

Isabel, O. (2007). Classic management style not engaging. Canadian HR Reporter, 20(15), 18-20.

Lowe, G.S., \& Schellenberg, G. (2002). Employees' basic value proposition: Strong HR strategies must address work values. Canadian HR Reporter, 15(13), 18-20.

Mainiero, L.A., \& Sullivan, S.E. (2006). The opt-out revolt: Why people are leaving companies to create kaleidoscope careers. Mountain View: Davies-Black.

Maitland, A. (2007, 27 September). Tailored careers can be just the job. Financial Times, p. 16.

Marriot, J.W. (2001). Our competitive strength: Human capital. Executive Speeches, 15(5), 18-21.
Marshall, C., \& Rossman, G.B. (1995). Designing qualitative research. (2nd edn.). Thousand Oaks: Sage.

Meyer, M. (2005). ASTD state of the industry HR and training in South Africa report 2005. Johannesburg: ASTD Global Network SA.

Mouton, J. (2001). How to succeed in your master's and doctoral studies: A South African guide and resource book. Pretoria: Van Schaik.

Muhr, T., \& Friese, S. (2004) User's manual for Atlas.ti. (2nd edn.). Berlin: Atlas.ti.

Myers, M.D. (1997). Qualitative research in information systems. Retrieved August 26, 2007, from http://www.qual.auckland. ac.nz

Noe, R.A., Hollenbeck, J.R., Gerhart, B., \& Wright, P.M. (2008). Human resource management: Gaining a competitive advantage. (6th edn.). Boston: McGraw-Hill Irwin.

Peterson, B. (2007). The employee value proposition: Six things you need to know. Retrieved June 20, 2007, from http://www.nettemps.com

Punch, K.F. (2005). Introduction to social research: Qualitative and quantitative approaches. London: Sage.

Robbins, S.P., Odendaal, A., \& Roodt, G. (2001). Organisational behaviour: Global and Southern African perspectives. Johannesburg: Maskew Miller Longman.

Saratoga Institute. (2005). Human capital benchmarking study. Resolve Workplace Solutions. Report presented to City of Johannesburg, South Africa.

Shaw, J.D., Duffy, M.K., Johnson, J.L., \& Lockhart, D.E. (2005). Turnover, social capital losses, and performance. Academy of Management Journal, 48, 594-606.

South Africa. 1996. Constitution of the Republic of South Africa. Retrieved August 27, 2007, from http://www. constitutionalcourt.org.za

Sparks, A.C. (2002). Telling tales in sport and physical activity: A qualitative journey. Leeds: Human Kinetics.

Sutherland, M.M (2004). Factors affecting the retention of knowledge workers. Retrieved November 15, 2007, from http://0etd.uj.ac. zaujlink.uj.ac.za/theses/available/etd-11172004-131718/

Swanepoel, B., Erasmus, B., Van Wyk, M., \& Schenk, H. (2003). South African human resource management. Johannesburg: Juta.

Ulrich, D. (1998). Delivering results: A new mandate for human resource professionals. Boston: Harvard Business School.

Welman, J.C., \& Kruger, S.J (1999). Research methodology for the business and administrative sciences. Cape Town: Oxford University Press.

Zingheim, P.K., \& Schuster, J.R. (2006). Career directions for total rewards professionals. Compensation and Benefits Review, 38(3), 18-25. 